\title{
Taphonomic Analysis of Micromammal Remains from Striped Owl (Pseudoscops clamator) Pellets in Northeastern Buenos Aires Province, Argentina: Implications for Archaeological Sites Formation
}

\author{
S. M. RUDZIK, ${ }^{\text {a }}$ F. J. FERNÁNDEZ ${ }^{a *}$ AND J. D. CARRERA ${ }^{a}$ \\ Cátedra de Anatomía Comparada, Facultad de Ciencias Naturales y Museo, Universidad Nacional de La \\ Plata, Buenos Aires, Argentina
}

\begin{abstract}
The main objective of this study was to determine the taxonomic and taphonomic characteristics of the micromammal remains recovered from pellets of Pseudoscops clamator (striped owl), collected at three localities in northeastern Buenos Aires Province, Argentina (Punta Lara Natural Reserve, 34 49'02,6"S, 5803'03,9'W; Costanera Sur Ecological Reserve, 34³6'6,44"S, 58²1'33,22"W; Los Robles Park, $\left.34^{\circ} 40^{\prime} 22,03^{\prime \prime} \mathrm{S}, 58^{\circ} 52^{\prime} 18,88^{\prime \prime} \mathrm{W}\right)$. The main taphonomic variables (e.g. evidence of digestive action, breakage patterns and relative abundance of skeletal elements) suggest that this owl mainly produces intermediate to moderate modification. On the other hand, $P$. clamator preyed mainly upon large-sized $(>150 \mathrm{~g})$ micromammals (e.g. Lutreolina crassicaudata, Cavia aperea, Holochilus brasiliensis and Rattus sp.), and to a lesser degree on medium- (50-150 g) and small-sized species (<50 g) (e.g. Scapteromys aquaticus, Calomys sp., Oligoryzomys flavescens, Akodon azarae and Mus musculus). Fossil assemblages with a dominance of large-sized micromammals are commonly associated with humans as agents of accumulation. However, this study demonstrates that this owl produces assemblages with abundant large-sized micromammals, which introduces an equifinality problem. In that sense, digestive corrosion marks, breakage patterns and the relative abundance of skeletal remains are the main attributes to differentiate $P$. clamator from humans, as agents of accumulation. Finally, our results might serve as an analytical model for the taphonomic interpretation of the fossil record of micromammals from paleontological and archaeological sites, which fall within the distributional range and habitat of $P$. clamator. Copyright () 2013 John Wiley \& Sons, Ltd.
\end{abstract}

Key words: equifinality; micromamalian assemblages; pellets; predation; South America; Strigiformes; taphonomy Supporting information may be found in the online version of this article.

\section{Introduction}

Actualistic taphonomic studies on micromammal remains produced by different predators constitute an appropriate analytical model for the interpretation of assemblages from archaeological and paleontological sites (e.g. Andrews, 1990; Fernández-Jalvo \& Andrews, 1992; Stahl, 1996; Denys, 2002; Terry, 2007; Souttou et al., 2012). In Argentina, this type of studies has been on the rise in recent years (Pardiñas, 1999, Gómez, 2005, 2007; Gómez \& Kauffmann, 2007; Montalvo et al., 2007, 2008, 2012; Iglesias, 2009; Montalvo \&

\footnotetext{
* Correspondence to: F. J. Fernández, Cátedra de Anatomía Comparada Facultad de Ciencias Naturales y Museo, Universidad Nacional de La Plata Buenos Aires, Argentina, Street 64 (1900), La Plata, Argentina. e-mail: fernandezf77@yahoo.com.ar
}

Tallade, 2009, 2010; Montalvo \& Tejerina, 2009; Carrera \& Fernández, 2010; Álvarez et al., 2012). However, even when a large part of micromammal assemblages from archaeological sites tend to be accumulated by Strigiformes, only a few of those studies have considered these raptor birds (Pardiñas, 1999; Gómez, 2005; 2007; Montalvo \& Tejerina, 2009; Carrera \& Fernández, 2010).

Carrera \& Fernández (2010) carried out an experimental taphonomic study on remains of Mus musculus (house mouse) consumed by Pseudoscops clamator (striped owl). The authors concluded that this species might fall into category I or 'with light modifications' (sensu Andrews, 1990). This mid-sized (320-500 g) owl nests on the ground, frequently perches upon trees and has nocturnal and crepuscular habits (del Hoyo et al., 1999; Pautasso \& 
de la Peña, 2001). It is distributed from Mexico, through large parts of the tropical and subtropical zone of Central and South America, down to La Pampa and Buenos Aires provinces in Argentina (Martinez et al., 1996; Marks et al., 1999). It is found in diverse habitats from sea level to $1400 \mathrm{~m}$ asl, including xerophytic forests, jungles, grasslands and suburban areas (Marks et al., 1999). Its diet is based mainly on rodents, and occasionally on birds, other vertebrates and insects (Massoia, 1988; Isacch et al., 2000; Motta-Junior et al., 2004; Delgado et al., 2005; Pautasso, 2006; Aguiar \& Naiff, 2009; Lo Coco et al., 2012). Most of the diet studies agree on the relatively large size of its prey items, in comparison with other South American Strigiformes, counting Holochilus spp. (marsh rats), Rattus spp. (rats) and Cavia aperea (Brazilian guinea pig) among its rodent prey. The larger size of this owl and its robust beak and hindlimbs (mainly tarsometatarsus and claws) might enable this owl to hunt for larger animals (see Motta-Junior, 2006).

This study focuses on the taphonomic analysis of micromammal remains recovered from pellets of $P$. clamator, collected in northeastern Buenos Aires province, Argentina. Moreover, comparisons are made with previous studies performed with other raptors, with special reference to the work of Carrera \& Fernández (2010) on P. clamator. Comparisons are made with the purpose of categorizing this owl as a taphonomic agent and relate its micromammals deposits with archaeological assemblages, mainly those derived from human accumulations.

\section{Materials and methods}

\section{Materials}

Bone and teeth remains from rodents and marsupials [number of identified specimens per taxon $(\mathrm{NISP})=5952$; minimum number of elements $(\mathrm{MNE})=5766_{;}$minimum number of individuals $(\mathrm{MNI})=103)$ ] were recovered from three samples of pellets of $P$. clamator from the northeastern Pampean Region (Figure 1):

(1) Punta Lara Natural Reserve (PLNR $34^{\circ} 49^{\prime} 02.6^{\prime \prime} \mathrm{S}$, $\left.58^{\circ} 03^{\prime} 03.9^{\prime \prime} \mathrm{W}\right)$. This reserve occupies an area of 6000 ha and has several habitat types including

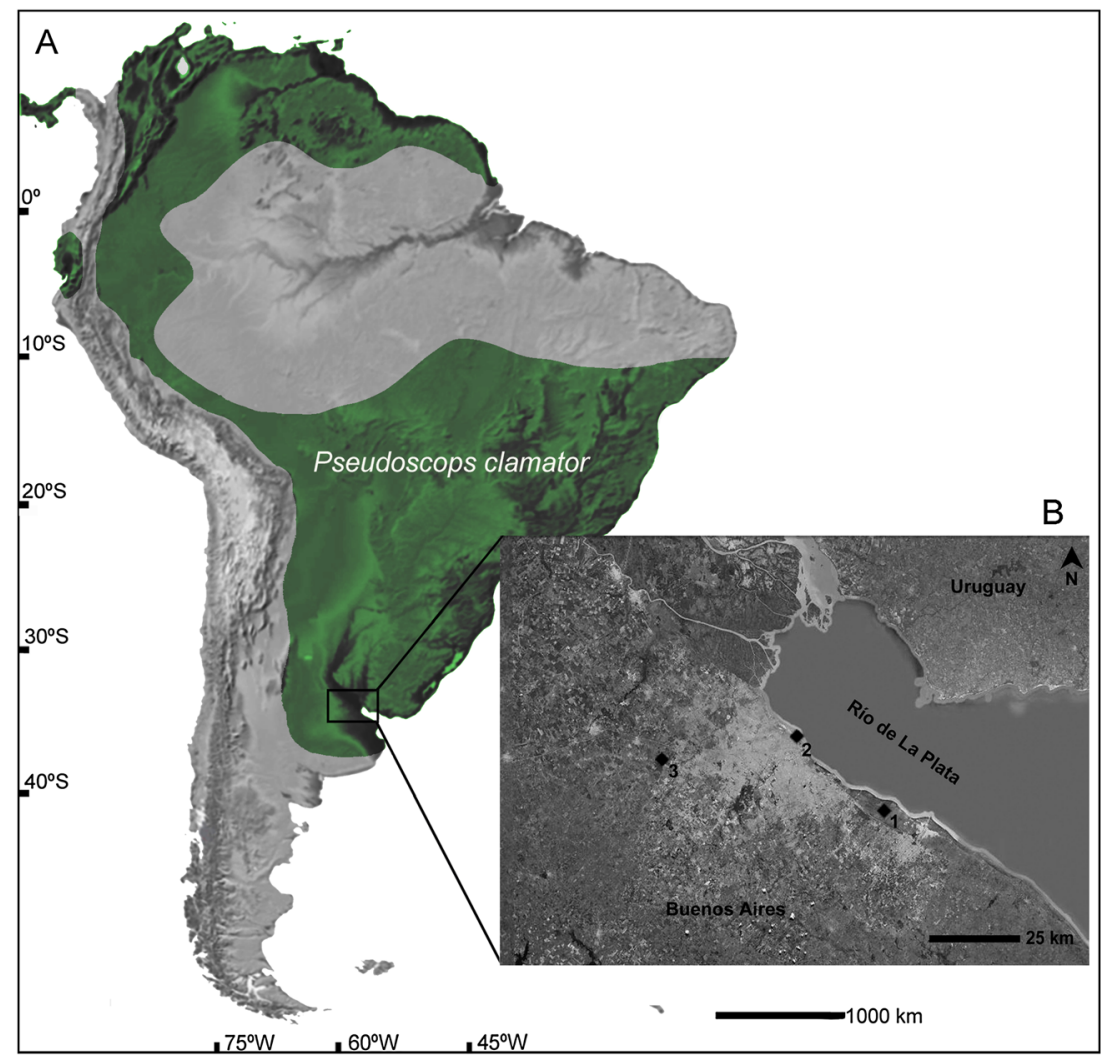

Figure 1. (A) Distribution of Pseudoscops clamator at South America. (B) Detail of the study area including the samples analyzed: 1. Punta Lara Natural Reserve (PLNR); 2. Costanera Sur Ecological Reserve (CSER); 3. Los Robles Park (LRP). This figure is available in colour online at wileyonlinelibrary. com/journal/oa. 
native grasslands, marshes, riverine forests and groves of Eucalyptus spp. (eucalyptus) and Celtis tala (tala), together with shallow lakes, channels and brooks. An adult individual of $P$. clamator was observed between November 2008 and January 2009, perched upon C. tala trees, and 24 pellets were recovered from that site. These samples yielded a $\mathrm{NISP}=1201 ; \mathrm{MNE}=1151$ and $\mathrm{MNI}=34$.

(2) Costanera Sur Ecological Reserve (CSER; $\left.34^{\circ} 36^{\prime} 6.44^{\prime \prime} \mathrm{S}, \quad 58^{\circ} 21^{\prime} 33.22^{\prime \prime} \mathrm{W}\right)$. This reserve occupies an area of 353 ha and presents shallow lakes surrounded by marshes, grasslands and groves of Tipuana tipu (tipu tree), Phoenix canariensis (Canary Island date palm) and Melia azedarach (chinaberry). In April 2009, a mating couple of P. clamator was found nesting in a dried grassland of Schoenoplectus californicus (totora), from where 21 pellets were recovered. These yielded a NISP $=1236 ; \mathrm{MNE}=1210$ and $\mathrm{MNI}=28$.

(3) Los Robles Park (LRP; $\left.34^{\circ} 40^{\prime} 22.03^{\prime \prime} \mathrm{S}, 58^{\circ} 52^{\prime} 18.88^{\prime \prime} \mathrm{W}\right)$. This park comprises an area of 1000 ha, with native grasslands, marshes and exotic species plantations. Between July and August 2010, a mating couple of P. clamator was found in a Salix bumboldtiana (pencil willow) grove stand surrounded by native grassland invaded by Gleditsia triacanthos (honey locust), from where 45 pellets were collected. These yielded a $\mathrm{NISP}=3515 ; \mathrm{MNE}=3405$ and $\mathrm{MNI}=41$.

The landscape of the region is composed of plains with some undulations, and the native vegetation is characterized by grasslands of Stipa, Poa and Bromus (Cabrera, 1976). The climate is dictated by the Atlantic anticyclone, with average annual precipitation $=1200 \mathrm{~mm}$ and average annual temperature $=18^{\circ} \mathrm{C}($ Burgos, 1968) .

\section{Methods}

Owl pellets were disaggregated while moist, after a quick dip in warm water. Bone and teeth were separated and studied under a dissecting scope. Remains were identified using reference materials from the mammal collection at Museo de La Plata and published references (e.g. Massoia \& Fornes, 1965; Massoia, 1976). Average weights for each taxon were obtained from a previous work performed on the same study area (Leveau et al., 2006), and the percent biomass contributed by each prey species was estimated as $\left(\mathrm{B}_{\mathrm{i}}\right)=\left[\left(\mathrm{Sp}_{\mathrm{i}} \mathrm{N}_{\mathrm{i}}\right) / \Sigma\left(\mathrm{Sp}_{\mathrm{i}} \mathrm{N}_{\mathrm{i}}\right)\right] \times 100$, where $S p_{i}$ is the weight of species $i, N_{i}$ is the number of consumed individuals of species i (Marti, 1987).

For the taphonomic analysis of micromammals, the classification proposed by Andrews (1990) and Fernández-Jalvo \& Andrews (1992) was followed. This classification makes the distinction between five categories of modification of skeletal and teeth remains (i.e. light, intermediate, moderate, heavy and extreme), including Strigiformes, Falconiformes and carnivore mammals. According to Andrews (1990), these categories are based both on degree of modification and frequencies of elements affected. Corrosion marks, produced by digestive acids, were observed on the surfaces of teeth (i.e. incisors and molars) and postcranial remains (i.e. proximal epiphysis of femur and distal epiphysis of humerus). Additionally, the degree of breakage of cranial and postcranial remains was analyzed by counting whole remains and the different portions (i.e. diaphysis, proximal epiphysis and distal epiphysis).

The relative abundance of skeletal elements was evaluated considering the representativity of each one in the sample $\left(\mathrm{MNE}_{\mathrm{i}}\right)$ as a function of the expected number of that specific skeletal element in the individual $\left(\mathrm{E}_{\mathrm{i}}\right)$ and $\mathrm{MNI}$, after: $\mathrm{MNE}_{\mathrm{i}}\left(\mathrm{E}_{\mathrm{i}} \times \mathrm{MNI}\right) \times$ 100. In order to analyze the relationships between cranial and postcranial elements, two indices were calculated: $I=[($ femur + tibia + humerus + radius + ulna $)$ $\times 16 /($ mandible + maxilla + molars $) \times 10] \times 100$, and $\mathrm{II}=[$ (humerus + femur $) /($ mandible + maxilla $)] \times 100 . \mathrm{In}$ order to study relationships between distal and proximal limb elements, the following index was calculated: $[$ (tibia + radius $) /($ femur + humerus $)] \times 100$. Additionally, two indices that evaluate the proportion of isolated teeth were calculated [(maxillary alveoli + mandibular alveoli)/ (molars) $] \times 100 ;$ and [(premaxillary alveoli + mandibular alveoli)/(incisors) $] \times 100$.

Micromammals (mammals $<1 \mathrm{~kg}$ ), were divided into three size-categories: small $(<50 \mathrm{~g})$, medium (between 50 and $150 \mathrm{~g})$ and large $(>150 \mathrm{~g})$ (modified from Pardiñas, 1996-1998).

Additionally, Pardiñas (1999) developed two indices to evaluate the action of raptor birds and humans in the origin of assemblages; namely (i) Size Index [(MNI ${ }_{\text {small }}+$ $\mathrm{MNI}$ medium $) /(\mathrm{MNI}$ large $)] \times 100$ and (ii) Predictability Index $[(\mathrm{MNI}$ colonial $+\mathrm{MNI}$ gregarious $+\mathrm{MNI}$ grouped $) /$ $\left(\mathrm{MNI}_{\text {cryptic }}+\mathrm{MNI}\right.$ solitary $\left.)\right] \times 100$. On the one hand, hystricognath (C. aperea) and murid (Rattus sp.) rodents are included in the grouped category, and on the other hand, cricetid rodents and marsupials correspond to the cryptic and solitary categories.

Finally, ordination (Principal Component Analysis, PCA) and grouping (Cluster Analysis) multivariate statistics were performed in order to test for relationships between micromammal samples produced by $P$. clamator and those generated by other Strigiformes from South America, North America, Europe, Asia and Africa, for which there exists taphonomic information. These tests were performed using the software PAleontological 
STatistics version 2.07 (Hammer, 1999-2011), which is based on a data matrix composed of the main taphonomic attributes considered (i.e. S1). Moreover, the similitude coefficient used in the cluster analysis was based on Euclidean distances, and the phenograms produced were plotted according to the Unweighted Pair Group Method Average method.

\section{Results}

\section{Predation}

Nine micromammal taxa were identified from pellets of $P$. clamator from the three locations considered, including a marsupial and eight rodents (Table 1).

A total of 34 prey items were registered in the sample from PLNR (expressed in $\mathrm{MNI}$ ). The main species were the hystricognath rodent C. aperea and the sigmodont rodent Holochilus brasiliensis (web-footed marsh rat), followed by the sigmodonts Akodon azarae (Azara's grass mouse), Scapteromys aquaticus (water rat), Oligoryzomys flavescens (yellow pygmy rice rat) and a juvenile of the didelphid marsupial Lutreolina crassicaudata (little water opossum). A total of 28 prey items were found in the sample from CSER, with O. flavescens being the most abundant species, and C. aperea and the introduced murid $M$. musculus found in smaller proportion. The sample from LRP yielded 41 prey items, with the introduced murid Rattus sp. being the most consumed species, followed by O. flavescens, C. aperea, Calomys sp. (vesper mice) and A. azarae.

In terms of biomass, C. aperea was important to the owl diet in the three samples analyzed, while $H$. brasiliensis and Rattus sp. contributed significantly to the total biomass in samples from PLNR and LRP, respectively (Table 1).

Size index values indicated that $P$. clamator preyed mainly upon large-sized micromammals (e.g. C. aperea, H. brasiliensis and Rattus sp.) in samples from PLNR and LRP, while it preyed upon small-sized rodents (e.g. O. flavescens and M. musculus) in the sample from CSER (Table 2).

Finally, predictability index values indicated that $P$. clamator mainly consumed micromammals with solitary habits (i.e. A. azarae, S. aquaticus, $H$. brasiliensis, $O$. flavescens, M. musculus and $L$. crassicaudata) in samples from PLNR and CSER, and predictable micromammals (i.e. C. aperea and Rattus sp.) in the sample from LRP (Table 2).

\section{Anatomical representation}

Average relative abundance of skeletal parts indicates a high integrity in samples from CSER and LRP and a medium integrity in PLNR (Table 3). Despite variations in some elements, samples from the three locations showed a similar representativity pattern of skeletal

Table 1. Average weight (W), minimum number of individuals (MNI), percentage of minimum number of individuals (MNI\%) and total percent biomass $(\% \mathrm{~B})$ of the taxa consumed by Pseudoscops clamator in the samples studied. For abbreviations, see Figure $1 \mathrm{caption}$

\begin{tabular}{|c|c|c|c|c|c|c|c|c|c|c|}
\hline & \multirow[b]{2}{*}{ W } & \multicolumn{3}{|c|}{ PLNR } & \multicolumn{3}{|c|}{ CSER } & \multicolumn{3}{|c|}{ LRP } \\
\hline & & $\mathrm{MNI}$ & $\mathrm{MNI} \%$ & $\% \mathrm{~B}$ & $\mathrm{MNI}$ & $\mathrm{MNI} \%$ & $\% \mathrm{~B}$ & $\mathrm{MNI}$ & $\mathrm{MNI} \%$ & $\% \mathrm{~B}$ \\
\hline \multicolumn{11}{|l|}{ Mammalia } \\
\hline \multicolumn{11}{|l|}{ Didelphimorphia } \\
\hline Lutreolina crassicaudata & 445 & 0 & 0 & 0 & 1 & 3.6 & 15 & 0 & 0 & 0 \\
\hline \multicolumn{11}{|l|}{$\begin{array}{l}\text { Rodentia } \\
\text { Caviidae }\end{array}$} \\
\hline Cavia aperea & 525 & 13 & 38.2 & 59.7 & 4 & 14.3 & 70.6 & 6 & 14.6 & 43.7 \\
\hline \multicolumn{11}{|l|}{ Muroidea } \\
\hline Cricetidae indet. & $19^{a}$ & 0 & 0 & 0 & 3 & 10.7 & 1.9 & 0 & 0 & 0 \\
\hline Calomys sp. & 14 & 0 & 0 & 0 & 0 & 0 & 0 & 1 & 2.4 & 0.2 \\
\hline Akodon azarae & 28 & 4 & 11.8 & 1 & 0 & 0 & 0 & 1 & 2.4 & 0.4 \\
\hline Scapteromys aquaticus & 112 & 2 & 5.9 & 2 & 0 & 0 & 0 & 0 & 0 & 0 \\
\hline Holochilus brasiliensis & 326 & 13 & 38.2 & 37 & 0 & 0 & 0 & 0 & 0 & 0 \\
\hline Oligoryzomys flavescens & 19 & 2 & 5.9 & 0.3 & 18 & 64.3 & 11.5 & 9 & 21.9 & 2.4 \\
\hline \multicolumn{11}{|l|}{ Muridae } \\
\hline Rattus sp. & 160 & 0 & 0 & 0 & 0 & 0 & 0 & 24 & 58.6 & 53.3 \\
\hline Mus musculus & 14 & 0 & 0 & 0 & 2 & 7.1 & 0.9 & 0 & 0 & 0 \\
\hline Total & & 34 & & & 28 & & & 41 & & \\
\hline
\end{tabular}

aData from O. flavescens, the single cricetid in CSER sample. 
Table 2. Values of the indices calculated for small mammals from Pseudoscops clamator samples studied: $f=$ femur; $t=$ tibia; $\mathrm{h}$ =humerus; $\mathrm{r}=$ radius; $\mathrm{c}=$ ulna; $\mathrm{mx}=$ maxilla; $\mathrm{mb}=$ mandible; $m=$ molar; i: incisor. For abbreviations, see Figure 1 caption

\begin{tabular}{lccr}
\hline & PLNR & CSER & LRP \\
\hline Postcranial/Cranial & & & \\
I. $f+\mathrm{t}+\mathrm{h}+\mathrm{r}+\mathrm{c} / \mathrm{m} x+\mathrm{mb}+\mathrm{m}$ & 401 & 379.5 & 384.4 \\
II. $\mathrm{h}+\mathrm{f} / \mathrm{m} \mathrm{x}+\mathrm{mb}$ & 132.9 & 136.4 & 115.2 \\
Distal/Proximal elements & & & \\
$\mathrm{t}+\mathrm{r} / \mathrm{f}+\mathrm{h}$ & 74.2 & 74.4 & 97.9 \\
$\%$ Isolated teeth & & & \\
Alveoli $\mathrm{mx}+$ alveoli $\mathrm{mb} / \mathrm{m}$ & 13.8 & 46.4 & 19.9 \\
Alveoli $\mathrm{mx}+$ alveoli $\mathrm{mb} / \mathrm{i}$ & 5.6 & 4.9 & 3.8 \\
Size index & 30.8 & 460 & 36.7 \\
Predictability index & 61.9 & 16.7 & 272.7 \\
& & & \\
\hline
\end{tabular}

parts, where the most abundant elements were the mandibles, humeri, femurs and tibias, while the least abundant were ribs and autopodia (Figure 2A). There were no important variations in the relative abundance of elements between the different size-classes of micromammals (Figure 2B).

On the other hand, the two indices evaluating the relationship between postcranial and cranial elements suggest a better preservation of the former in all samples (Table 2). The index quantifying the relationship between distal and proximal limbs indicates an abundance of proximal elements in the samples from PLNR and CSER, and an even representativity in LRP. Finally, the teeth loss indices showed that in all samples, most molars and incisors were retained in their alveoli (Table 2).

\section{Digestion}

$82 \%$ of skeletal and teeth remains suffered some degree of alteration, due to digestive action. The light and moderate modification categories were the most frequent ones $(45.7 \%$ and $27.9 \%$, respectively), followed by the heavy $(8.3 \%)$ and extreme $(0.1 \%)$ categories (Table 4).

In samples from PLNR and LRP, $>80 \%$ of remains showed corrosion marks, mainly in the light (PLNR = $42.8 \%$ and $\mathrm{LRP}=46.6 \%$ ) and moderate categories $(\mathrm{PLNR}=25.9 \%$ and LRP $=32.9 \%)$. On the other hand, the sample from CSER presented a light reduction, with percentages $<70 \%$, especially in the light $(41.2 \%)$ and moderate categories (16.9\%). In that sense, a part of postcranial remains showed small pits on the epiphysis surfaces, and some appeared to be polished (Figure 3A-F). Some molars showed cups with a rounded contour, while some others showed small cracking and scaling in the enamel (Figure 3G). Corrosion was more intense on some incisors tips, while on others, it extended to a larger surface, leaving them with an undulated appearance (Figure $3 \mathrm{H}-\mathrm{I}$ ).

\section{Breakage}

$29.8 \%$ of all specimens recovered from samples showed some degree of breakage. Moreover, the proportion of breakage elements across the different samples was simi$\operatorname{lar}(\mathrm{PLNR}=22.6 \% ; \mathrm{CSER}=29.2 \%$ and $\mathrm{LRP}=32.5 \%)$.

Table 3. Minimum number of elements (MNE) and relative abundances of elements for small mammals from Pseudoscops clamator samples studied. For abbreviations, see Figure 1 caption

\begin{tabular}{|c|c|c|c|c|c|c|}
\hline & \multicolumn{2}{|r|}{ PLNR } & \multicolumn{2}{|r|}{ CSER } & \multicolumn{2}{|r|}{ LRP } \\
\hline & MNE & Relative abundance & MNE & Relative abundance & MNE & Relative abundance \\
\hline Maxilla & 22 & 32.4 & 29 & 51.8 & 60 & 73.2 \\
\hline Mandible & 48 & 70.6 & 37 & 66.1 & 65 & 79.3 \\
\hline Isolated incisors & 7 & 5.2 & 44 & 39.3 & 52 & 31.7 \\
\hline Isolated molars & 9 & 1.7 & 12 & 3.6 & 24 & 3.7 \\
\hline Vertebra & 372 & 36.5 & 326 & 38.8 & 960 & 78 \\
\hline Ribs & 107 & 13.1 & 190 & 28.3 & 575 & 58.4 \\
\hline Scapula & 17 & 25 & 28 & 50 & 46 & 56.1 \\
\hline Humerus & 51 & 75 & 35 & 62.5 & 75 & 91.5 \\
\hline Ulna & 36 & 52.9 & 28 & 50 & 73 & 89 \\
\hline Radius & 29 & 42.6 & 33 & 58.9 & 67 & 81.7 \\
\hline Pelvis & 31 & 45.6 & 33 & 58.9 & 81 & 98.8 \\
\hline Femur & 42 & 61.8 & 55 & 98.2 & 69 & 84.1 \\
\hline Tibia & 40 & 58.8 & 34 & 60.7 & 74 & 90.2 \\
\hline Calcaneus & 19 & 27.9 & 11 & 19.6 & 44 & 53.7 \\
\hline Astragalus & 4 & 5.9 & 5 & 8.9 & 38 & 46.3 \\
\hline Metapodia & 116 & 17.1 & 149 & 26.6 & 252 & 30.7 \\
\hline Phalange & 201 & 10.6 & 161 & 10.3 & 850 & 37 \\
\hline $\begin{array}{l}\text { Total } \\
\text { Average }\end{array}$ & 1151 & 32.3 & 1210 & 48.2 & 3405 & 63.2 \\
\hline
\end{tabular}




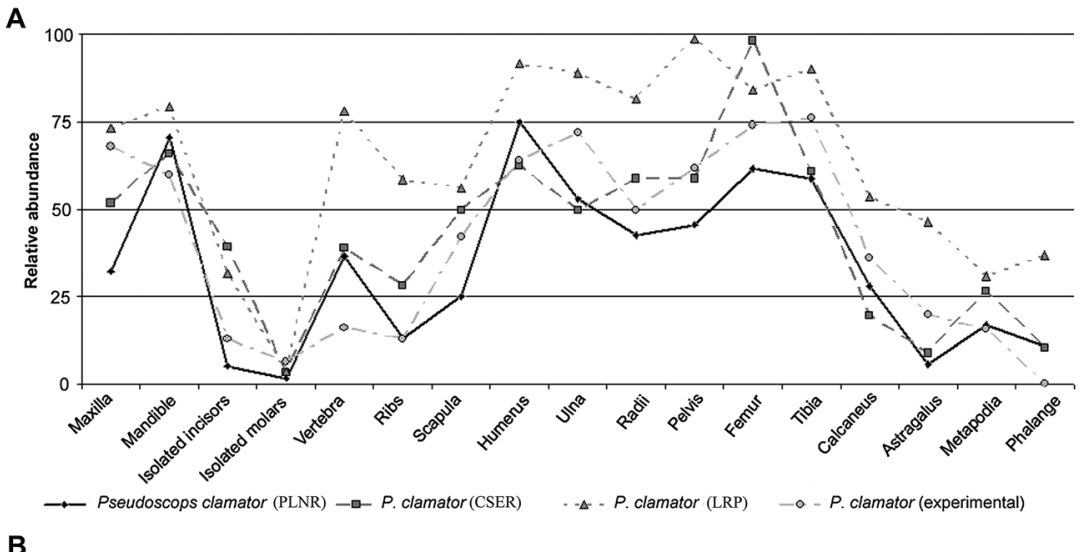

B

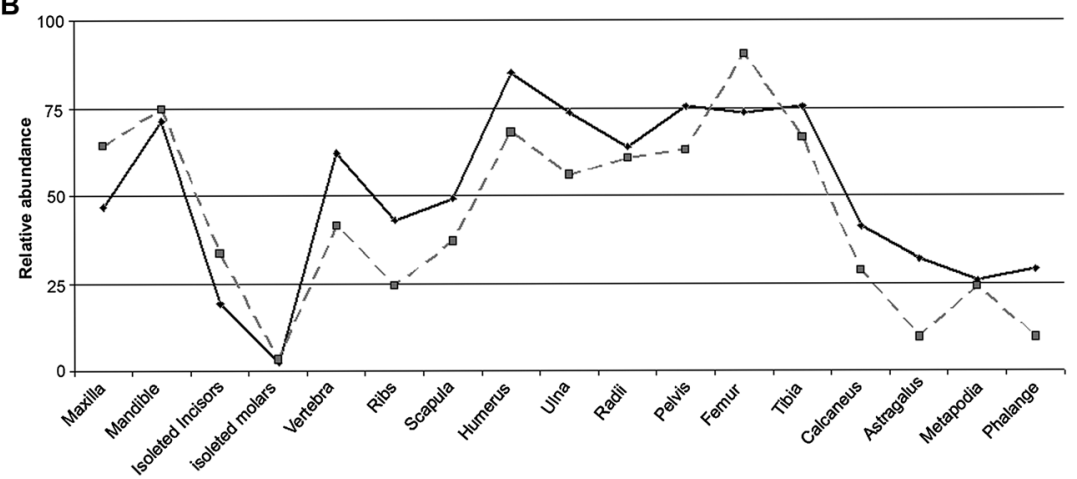

C

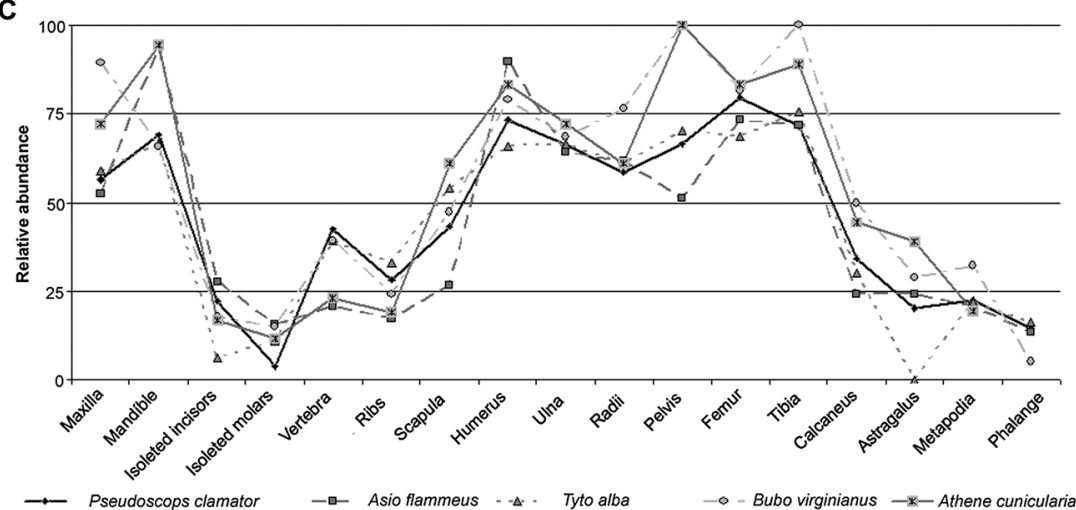

Figure 2. Values of relative abundance of different anatomical elements, comparing samples produced by Pseudoscops clamator (A), groups of sizes of micromammals produced by $P$. clamator (B), and average of the values of $P$. clamator (this work, and Carrera \& Fernández, 2010), Asio flammeus (Andrews, 1990), Tyto alba (Andrews, 1990), Bubo virginianus (Gómez, 2005) and Athene cunicularia (Montalvo \& Tejerina, 2009) (C). For abbreviations, see Figure 1 caption.

Table 5 shows the different types of breakage in the cranial and postcranial elements.

Few complete crania were found, and most of them were highly broken with loss of parietal and frontal elements $(\mathrm{PLNR}=95.3 \% ; \mathrm{CSER}=100 \%$ and $\mathrm{LRP}=98.9 \%)$. Most corresponded to maxillar and zygomatic arches, and other minor isolated remains (e.g. tympanic bullae and premaxillars). Moreover, the loss of molars from maxillars was light in all samples, and the loss of incisors from premaxillars was minimal in samples from PLNR, and even absent in CSER and LRP (Table 5).

Those samples from PLNR and CSER registered a moderate proportion of complete mandibles, while the sample from LRP yielded few complete mandibles (Table 5). A part of broken mandibles preserved the ascending branches in good condition, and very few mandibles presented a broken lower border of the mandibular branch (Table 5). The loss of incisors from 
Table 4. Representation of the various categories of digestive corrosion for small mammals from Pseudoscops clamator samples studied. For abbreviations, see Figure 1 caption

Digestion classes sensu Andrews (1990)

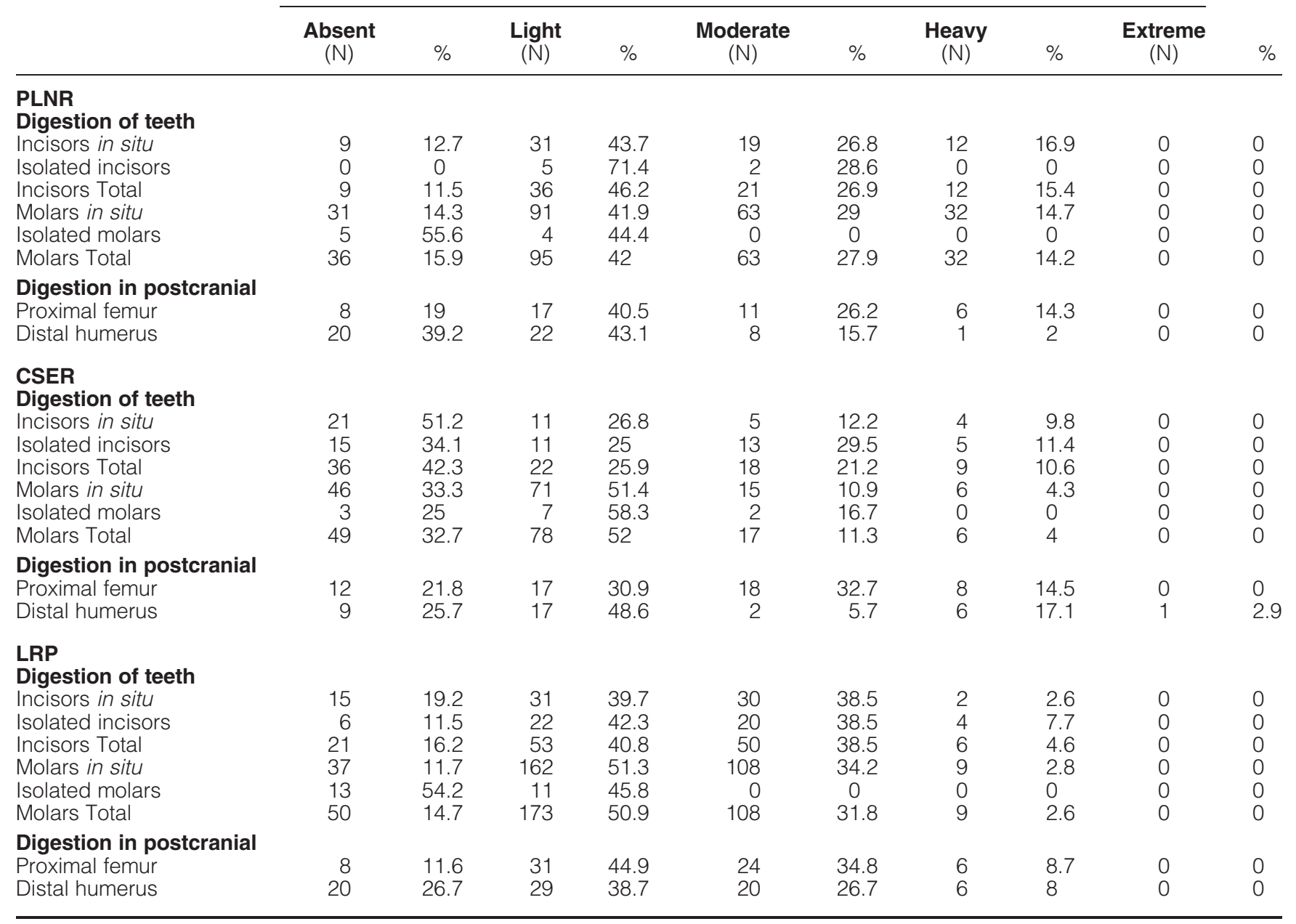

the mandibles was light in all samples, and the loss of molars was scarce in the sample from PLNR, and moderate in CSER and LRP (Table 5).

In all samples, the proportion of broken teeth was small $(\mathrm{PLNR}=1.3 \% ; \mathrm{CSER}=2.1 \%$ and $\mathrm{LRP}=0.6 \%)$, and particularly for incisors, those that were found in isolation were more broken up than those found in situ (Table 5).

Breakage values for postcranial elements were moderate in all samples $(\mathrm{PLNR}=21 \% ; \mathrm{CSER}=39.8 \%$ and $\mathrm{LRP}=18.5 \%)$. Moreover, the proximal epiphysis prevailed in the femur and ulna, while in the humerus and tibia, it was the distal epiphysis that predominated (Table 5). It is noteworthy, that all samples had a larger proportion of broken postcranial elements, with breakage surfaces at obtuse angles and smooth edges $(\mathrm{PLNR}=76.3 \% ; \mathrm{CSER}=72.9 \%$ and $\mathrm{LRP}=94.7 \%)$.
Finally, in all samples, the majority of autopodia elements (i.e. calcanea, astragalus, metapodia and phalanges) were complete (PLNR $=0.3 \%$; CSER $=8.6 \%$ and $L R P=0.1 \%)$. However, the most fragile elements such as ribs, scapulae and pelvis presented a high degree of breakage in all samples (Table 5).

\section{Discussion}

Multivariate analyses (Figure 4) yielded coherent values separating samples of $P$. clamator with respect to the other owl species compared. Specifically, axis 1 of the PCA (39.4\% of variance; Figure 4A), P. clamator showed a marked separation from Tyto alba (barn owl), Bubo lacteus (Verreaux's eagle owl), Strix nebulosa (great grey owl) and Asio otus (long eared owl); moderate separation from 

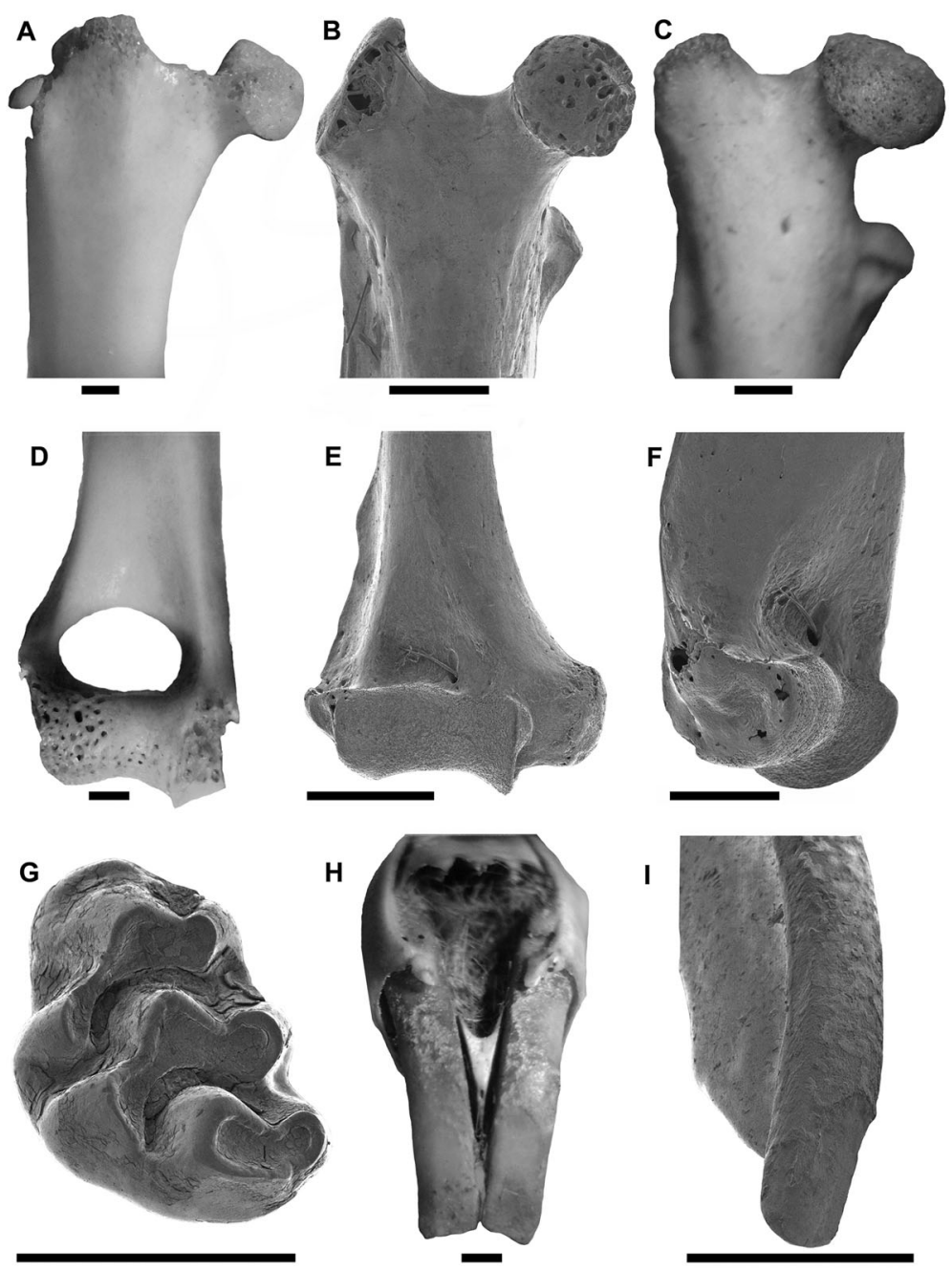

Figure 3. Different types of digestive alteration in remains recovered from Psendoscops clamator samples analyzed. (A) Femur of Cavia aperea with light alteration (CSER). (B) Femur of Muroidea with moderate alteration (CSER). (C) Femur de Rattus sp. with light alteration (LRP). (D) Humerus of C. aperea with moderate alteration (CSER). (E) Humerus of Muroidea with light alteration (CSER). (F) Humerus of C. aperea with light alteration (CSER). (G) Isolated molar of Mus musculus with light alteration (CSER). (H) Upper incisors of Holochilus brasiliensis with moderate alteration (PLNR). (I) Upper incisor of Muroidea with moderate alteration (CSER). Scales: $1 \mathrm{~mm}$. For abbreviations, see Figure 1 caption.

Asio flammeus (short-eared owl), Bubo bubo (european eagle owl), Strix aluco (tawny owl), Bubo virginianus (great horned owl), Bubo africanus (apotted eagle owl), and close to Athene cunicularia (burrowing owl). While axis 2 (24.4\% of variance) showed a marked separation from $B$. africanus and S. aluco, moderate separation from A. flammeus, B. bubo, B. virginianus, B. lacteus and $S$. nebulosa, and close to $A$. cunicularia, T. alba and A. otus. Moreover, the phenogram generated from cluster analysis shows more clearly the separation between the $P$. clamator samples, and the others owl species (Figure 4B).

Previous studies on the taphonomy of different Strigiform species have shown that the digestive activity of these birds characteristically affects bone and teeth remains in light to moderate categories (e.g. S1; Andrews, 1990; Gómez, 2005, 2007, Carrera \& Fernández, 2010, Montalvo \& Tejerina, 2010). In that sense, $P$. clamator mainly caused light and moderate digestive corrosion alterations in high porcentages (Table 4, S1), to the wild micromammal assemblages analyzed in this study, as well as in an experimental sample studied by Carrera \& Fernández (2010). Also, high and moderate frequencies of digestive corrosion were registered in micromammal assemblages generated by $A$. cunicularia, Bubo spp., Strix spp. and A. otus. (S1; Andrews, 1990; Gómez, 2007; Montalvo \& Tejerina, 2010). While in those assemblages generated by $T$. alba, A. flammens presented lower levels of corrosion (S1; Andrews, 1990). 
Table 5. Breakage in cranial, dental and post-cranial elements for small mammals from Pseudoscops clamator samples studied. For abbreviations, see Figure 1 caption

\begin{tabular}{|c|c|c|c|c|c|c|}
\hline & \multicolumn{2}{|c|}{ PLNR } & \multicolumn{2}{|c|}{ CSER } & \multicolumn{2}{|c|}{ LRP } \\
\hline & $N$ & $\%$ & $\mathrm{~N}$ & $\%$ & $\mathrm{~N}$ & $\%$ \\
\hline $\begin{array}{l}\text { Breakage of skulls } \\
\text { Complete skull } \\
\text { Maxillary with zygomatic } \\
\text { Maxillary without zygomatic } \\
\text { Minor fragments } \\
\text { Molars missing from maxillary } \\
\text { Incisors missing from premaxillary }\end{array}$ & $\begin{array}{r}2 \\
12 \\
8 \\
21 \\
13 \\
1\end{array}$ & $\begin{array}{r}4.7 \\
27.9 \\
18.6 \\
48.8 \\
12.3 \\
3.6\end{array}$ & $\begin{array}{r}0 \\
3 \\
26 \\
0 \\
27 \\
0\end{array}$ & $\begin{array}{c}0 \\
10.3 \\
89.7 \\
0 \\
28.7 \\
0\end{array}$ & $\begin{array}{r}1 \\
4 \\
55 \\
32 \\
23 \\
0\end{array}$ & $\begin{array}{c}1.1 \\
4.3 \\
59.8 \\
34.8 \\
12.2 \\
0\end{array}$ \\
\hline $\begin{array}{l}\text { Breakage of mandible } \\
\text { Complete mandible } \\
\text { Ascendant ramus broken } \\
\text { Without ascendant ramus } \\
\text { Without ascendant ramus and inferior edge broken } \\
\text { Molars missing from mandible } \\
\text { Incisors missing from mandible }\end{array}$ & $\begin{array}{r}15 \\
17 \\
12 \\
4 \\
17 \\
3\end{array}$ & $\begin{array}{c}31.2 \\
35.4 \\
25 \\
8.3 \\
12.1 \\
6.4\end{array}$ & $\begin{array}{r}14 \\
8 \\
12 \\
3 \\
37 \\
2\end{array}$ & $\begin{array}{r}37.8 \\
21.6 \\
32.4 \\
8.1 \\
34.3 \\
5.4\end{array}$ & $\begin{array}{r}11 \\
28 \\
20 \\
6 \\
40 \\
3\end{array}$ & $\begin{array}{r}16.9 \\
43.1 \\
30.8 \\
9.2 \\
21.1 \\
4.7\end{array}$ \\
\hline $\begin{array}{l}\text { Breakage of teeth } \\
\text { Broken molars in situ } \\
\text { Broken isolated molars } \\
\text { Total broken molars } \\
\text { Broken incisors in situ } \\
\text { Broken isolated incisors } \\
\text { Total broken incisors }\end{array}$ & $\begin{array}{l}2 \\
0 \\
2 \\
1 \\
1 \\
2\end{array}$ & $\begin{array}{c}0.9 \\
0 \\
0.9 \\
1.4 \\
14.3 \\
2.6\end{array}$ & $\begin{array}{l}1 \\
0 \\
1 \\
1 \\
3 \\
4\end{array}$ & $\begin{array}{r}0.7 \\
0 \\
0.7 \\
2.4 \\
42.9 \\
8.3\end{array}$ & $\begin{array}{l}1 \\
0 \\
1 \\
1 \\
1 \\
2\end{array}$ & $\begin{array}{l}0.3 \\
0 \\
0.3 \\
1.3 \\
5.8 \\
1.5\end{array}$ \\
\hline $\begin{array}{l}\text { Breakage of postcranial elements } \\
\text { Femur } \\
\text { Complete } \\
\text { Proximal } \\
\text { Shaft } \\
\text { Distal }\end{array}$ & $\begin{array}{r}34 \\
8 \\
0 \\
4\end{array}$ & $\begin{array}{c}73.9 \\
17.4 \\
0 \\
8.7\end{array}$ & $\begin{array}{r}35 \\
20 \\
2 \\
1\end{array}$ & $\begin{array}{r}60.3 \\
34.5 \\
3.4 \\
1.7\end{array}$ & $\begin{array}{r}55 \\
14 \\
0 \\
6\end{array}$ & $\begin{array}{c}73.3 \\
18.7 \\
0 \\
8\end{array}$ \\
\hline $\begin{array}{l}\text { Humerus } \\
\text { Complete } \\
\text { Proximal } \\
\text { Shaft } \\
\text { Distal }\end{array}$ & $\begin{array}{r}48 \\
0 \\
0 \\
3\end{array}$ & $\begin{array}{l}94.1 \\
0 \\
0 \\
5.9\end{array}$ & $\begin{array}{r}25 \\
0 \\
1 \\
10\end{array}$ & $\begin{array}{c}69.4 \\
0 \\
2.8 \\
27.8\end{array}$ & $\begin{array}{r}71 \\
1 \\
0 \\
4\end{array}$ & $\begin{array}{l}93.4 \\
1.3 \\
0 \\
5.3\end{array}$ \\
\hline $\begin{array}{l}\text { Tibia } \\
\text { Complete } \\
\text { Proximal } \\
\text { Shaft } \\
\text { Distal }\end{array}$ & $\begin{array}{r}30 \\
7 \\
1 \\
10\end{array}$ & $\begin{array}{r}62.5 \\
14.6 \\
2.1 \\
20.8\end{array}$ & $\begin{array}{r}22 \\
12 \\
3 \\
12\end{array}$ & $\begin{array}{r}44.9 \\
24.5 \\
6.1 \\
24.5\end{array}$ & $\begin{array}{r}66 \\
7 \\
2 \\
8\end{array}$ & $\begin{array}{r}79.5 \\
8.4 \\
2.4 \\
9.6\end{array}$ \\
\hline $\begin{array}{l}\text { Ulna } \\
\text { Complete } \\
\text { Proximal } \\
\text { Shaft } \\
\text { Distal }\end{array}$ & $\begin{array}{r}31 \\
5 \\
0 \\
0\end{array}$ & $\begin{array}{c}86.1 \\
13.9 \\
0 \\
0\end{array}$ & $\begin{array}{r}21 \\
7 \\
0 \\
0\end{array}$ & $\begin{array}{r}75 \\
25 \\
0 \\
0\end{array}$ & $\begin{array}{r}59 \\
14 \\
0 \\
1\end{array}$ & $\begin{array}{c}79.7 \\
18.9 \\
0 \\
1.4\end{array}$ \\
\hline $\begin{array}{l}\text { Breakage of others postcranial elements } \\
\text { Vertebra } \\
\text { Rib } \\
\text { Scapula } \\
\text { Radius } \\
\text { Pelvis } \\
\text { Calcaneus } \\
\text { Astragalus } \\
\text { Metapodia } \\
\text { Phalange }\end{array}$ & $\begin{array}{r}24 \\
75 \\
18 \\
0 \\
37 \\
0 \\
0 \\
1 \\
0\end{array}$ & $\begin{array}{c}6.5 \\
70.1 \\
85.7 \\
0 \\
84.1 \\
0 \\
0 \\
0.9 \\
0\end{array}$ & $\begin{array}{r}46 \\
97 \\
27 \\
8 \\
30 \\
0 \\
0 \\
28 \\
0\end{array}$ & $\begin{array}{l}14.1 \\
51 \\
96.4 \\
24.2 \\
75 \\
0 \\
0 \\
18.8 \\
0\end{array}$ & $\begin{array}{r}288 \\
477 \\
44 \\
4 \\
122 \\
1 \\
0 \\
0 \\
0\end{array}$ & $\begin{array}{r}30 \\
83 \\
81.5 \\
5.9 \\
91.7 \\
2.3 \\
0 \\
0 \\
0\end{array}$ \\
\hline
\end{tabular}

Conversely, digestive action values produced by micromammal assemblages from human origins show an elevated degree of corrosion ( $\mathrm{S} 1$; Crandall \& Stahl, 1995; Dewar \& Jerardino, 2007), comparable to those produced by carnivore mammals (e.g. Andrews \& Evans,
1983; Andrews, 1990; Gómez \& Kaufmann, 2007; Montalvo et al., 2007, 2008, 2012).

Figure $2 \mathrm{C}$ shows that the relative abundance patterns of skeletal parts from $P$. clamator samples and those from other species of Strigiformes from the area, such 


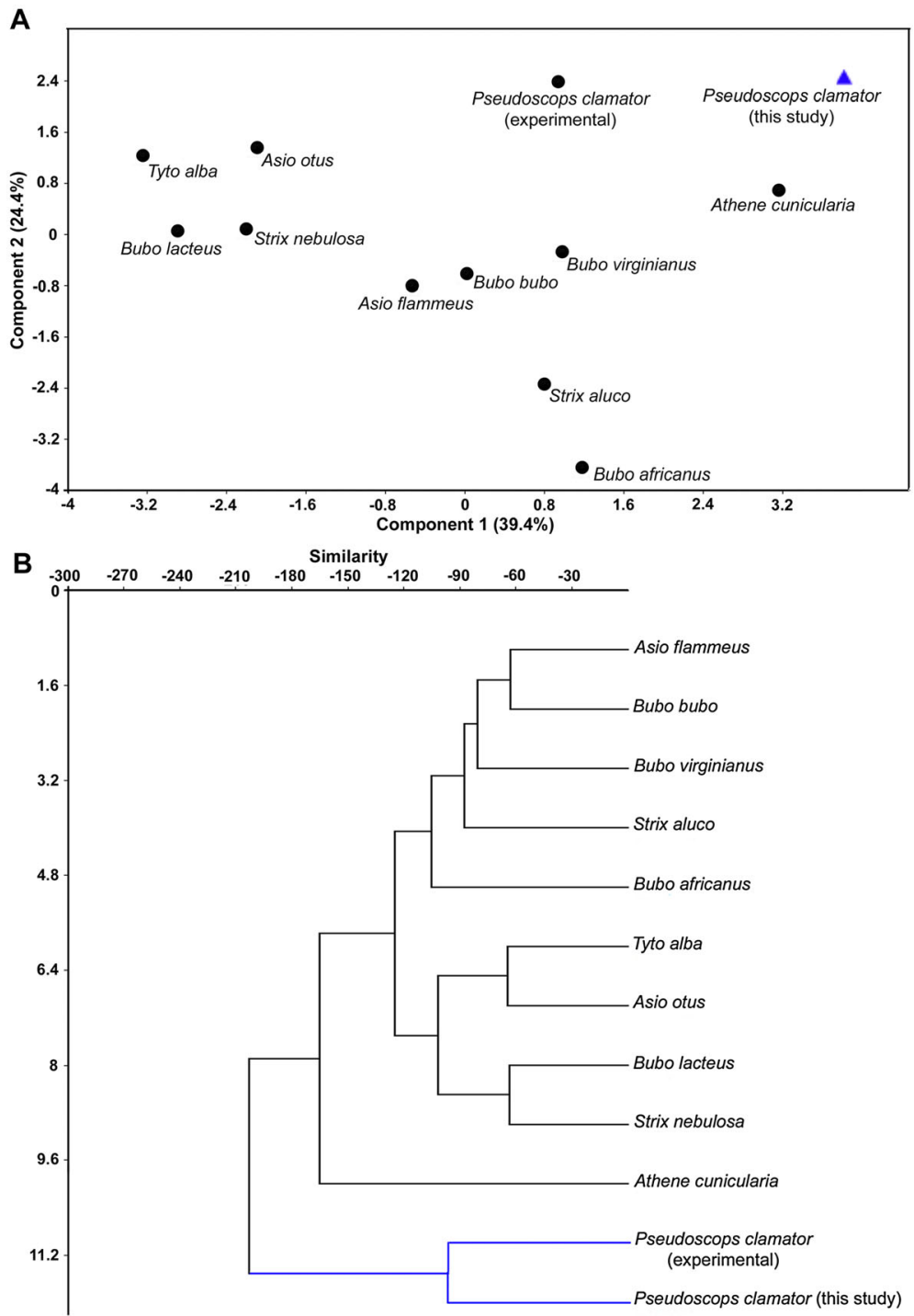

Figure 4. Multivariate analyses of small mammal samples of Pseudoscops clamator (this work, and Carrera \& Fernández, 2010), averages of Asio flammeus (Andrews, 1990), Tyto alba (Andrews, 1990), Bubo virginianus (Gómez, 2005), and Atbene cunicularia (Montalvo \& Tejerina, 2009), Bubo bubo (Andrews, 1990), Bubo lacteus (Andrews, 1990), Bubo africanus (Andrews, 1990), Asio otus (Andrews, 1990), Strix aluco (Andrews, 1990), and Strix nebulosa (Andrews, 1990). (A) Principal component analysis. (B) Cluster analysis $(\mathrm{ccc}=0.8573)$. For abbreviations, see Figure 1 caption. This figure is available in colour online at wileyonlinelibrary.com/journal/oa.

as A. flammeus, T. alba, B. virginianus and A. cunicularia, are fairly similar, with the most abundant elements being mandibles, humeri, femurs and tibias, while ribs and autopodia elements were the least frequent ones. However, in terms of average relative abundance, the samples generated by $P$. clamator exhibited a wide range of values (Table 3), above and below the values for the others of species of Strigiformes (S1). Moreover, the average relative abundance of skeletal parts from micromammal assemblages generated by humans is low $(13-33 \%)$, and the patterns clearly show a dominance of maxillars, humeri elements (Crandall \& Stahl, 1995; Dewar \& Jerardino, 2007).
Contrary to Falconiformes, carnivore mammals and humans (cf. Andrews, 1990; Andrews \& Evans, 1983; Dewar \& Jerardino, 2007), Strigiform birds usually ingest their prey whole, producing light-to-moderate breakage levels in skeletal elements (S1). The analyzed $P$. clamator samples showed light to moderate values (Table 5, S1).

In the three samples analyzed in this study and the experimental sample analyzed by Carrera \& Fernández (2010), postcranial elements were better preserved (Table 2, S1). Likely, Andrews (1990), Gómez (2007) and Montalvo \& Tejerina (2010) found that most of the assemblages derived from Strigiformes presented 
higher proportions of these elements (S1). It is noteworthy that in three archaeological sites from central Chile, Saavedra (1994) observed that the micromammal assemblages presented more cranial elements in largesized rodents and an equilibrium of these elements in small-sized rodents (Saavedra, 1994: Figure 2: 14). This differential pattern was attributed to the fact that the cranium of large rodents might have been separated before consumption of postcranial elements by humans. Moreover, Dewar \& Jerardino (2007) registered a complementary pattern in the micromammal assemblage recovered from a Late Stone Age occupation site in Namaqualand, South Africa (KVS02) and an assemblage recovered from the abdominal cavity of a human skeleton nearby (GRM5). In the first case (KVS02), cranial remains almost without digestive modifications $(0.6 \%)$ dominated, while in the second case (GRM5), only postcranial remains with high levels of digestive corrosion $(52.5 \%$, mainly in heavy category) and breakage $(100 \%)$ were found $(\mathrm{S} 1)$.

In general, both wild animals and humans generate micromammal assemblages in which proximal elements dominate, which is attributed to the fact that distal elements are more fragile (S1; Andrews, 1990; Dewar \& Jerardino, 2007). Accordingly, it was observed that $P$. clamator tends to produce micromammal assemblages with loss of distal limb elements (Table 2, S1). Moreover, in coincidence to several species of Strigiform, the assemblages generated by $P$. clamator presented their teeth in the alveoli of maxillars and mandibles (Table 2, S1).

Following the classification proposed by Andrews (1990), the results allow us to place $P$. clamator mostly in the category of moderate modification. However, our analysis indicates that the taphonomic alterations produced by this owl also include the light, intermediate and heavy categories (Figure 5, S1). In that sense, tooth loss, breakage of teeth and average of relative abundance showed the smaller modification values in all samples. The values of postcranial element breakage, the proportion of cranial elements with respect to postcranial elements (Index II) and the distal elements loss fall in the intermediate category. The remains affected by digestive corrosion, the proportion of breakage of mandibles and the proportion of cranial elements with respect to postcranial elements (Index I) fell in moderate category. Finally, cranial breakage was included within the heavy modification category, while it should be mentioned that this variable could be affected by the processing of pellet samples in the lab (see Methods). These categories differ markedly from humans, who fall within the highest modification category (extreme) of micromammal assemblages (Crandall \& Stahl, 1995; Dewar \& Jerardino, 2007).

Simonetti \& Cornejo (1991) and Pardiñas (1999) proposed that archaeofaunistic assemblages from South America with a dominance of large-sized and predictable micromammals might be associated with human consumption. In that sense, numerous micromammal assemblages from archaeological sites in southern South America have been attributed to human consumption due to this feature and other taphonomic variables, such as cut marks, thermal alteration and skeletal part patterns (e.g. El Manzano 1, La Batea 1 [Simonetti \& Cornejo, 1991], Arroyo El Gaucho 1 [Rivero et al., 2008], Quebrada del Real 1 [Medina et al., 2011], La Bellaca 2, Las Vizcacheras [Acosta \& Pafundi, 2005], Laguna Grande [Lezcano, 1991], Cueva Tixi [Quintana, 2005], Angostura 1, [Fernández et al., 2011], Cueva and Paredón Loncomán, Cueva Sarita IV [Pardiñas, 1999; Teta et al., 2005], Cueva Grande del Arroyo Feo, Cueva de las Manos, Cerro de los Indios [Mengoni, 1983], Orejas de Burro, El Condor 1 [Pardiñas et al., 2011]).

Nevertheless, at locations within PLNR and LRP, P. clamator preyed mainly upon large-sized micromammals

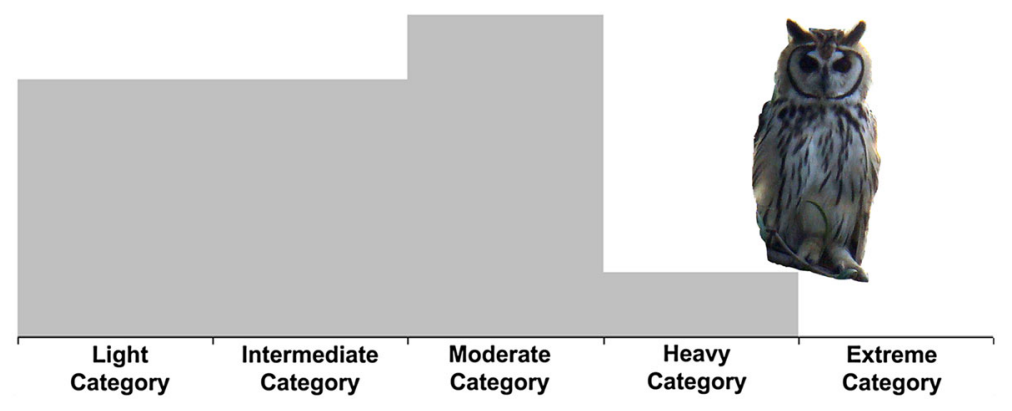

Figure 5. Bar diagram of Pseudoscops clamator categorization according to variables considered (cf. Andrews, 1990). This figure is available in colour online at wileyonlinelibrary.com/journal/oa. 
(Tables 1 and 2). Coincidentally, the dominance of large-sized prey such as $L$. crassicaudata, C. aperea, $H$. brasiliensis and Rattus spp. in the diet of $P$. clamator has already been mentioned in the literature (e.g. Massoia, 1988; Isaach et al., 2000; Pautasso, 2006; Baladrón, 2008). This tendency in predatory patterns was probably facilitated by the large size and robustness of the beak and hindlimbs (see Motta-Junior, 2006), a feature uncommon among other South American Strigiformes of comparable body mass (e.g. A. flammeus, T. alba). In that sense, it is suggested that the digestive corrosion marks, patterns of breakage and relative abundance of skeletal parts might be the main attributes to be used in the differentiation of this taphonomic agent, from humans.

\section{Conclusions}

From the taphonomic variables analyzed, it can be suggested that $P$. clamator is borderline between intermediate and moderate modification categories, coincident with the upper limit of the 'Strigiformes model', such as A. cunicularia and Bubo spp. (Andrews, 1990; Montalvo \& Tejerina, 2009).

Fossil assemblages rich in postcranial remains from large-sized micromammals may be associated with humans acting as agents of accumulation. However, the evidence presented in this study demonstrated that $P$. clamator is able to produce assemblages of large-sized micromammal postcranial remains, which introduces an equifinality problem. In that sense, digestive corrosion marks, breakage patterns and the relative abundance of skeletal remains are the main attributes to differentiate this owl from humans, as agents of accumulation.

Finally, our results might serve as an analytical model for the taphonomic interpretation of the fossil record of micromammals from paleontological and archaeological sites, which fall within the distributional range and habitat of $P$. clamator.

\section{Acknowledgements}

We acknowledge the labor of Germán Natoli in the field, the advice of Luciano De Santis and Pablo Teta, the collaboration of park rangers at PLNR and LRP and the critical comments of the reviewers at the first version of the manuscript. Financial and institutional support came from CONICET and Facultad de Ciencias Naturales y Museo.

\section{References}

Acosta A, Pafundi L. 2005. Zooarqueología y tafonomía de Cavia aperea en el humedal del Paraná inferior. Intersecciones en Antropología 6: 59-74.

Andrews P. 1990. Owls, Caves and Fossils. University of Chicago Press: Chicago.

Andrews P, Evans EMN. 1983. Small mammal bone accumulations produced by mammalian carnivores. Paleobiology 9 : 289-301.

Aguiar KM, Naiff RH. 2009. Aspectos reprodutivos e dieta alimentar dos ninhegos de Rbinoptynx clamator (Aves: Strigidae) no campus Marco Zero da Universidade Federal do Amapá, Macapá-AP. Acta Amazónica 39: 221-224.

Álvarez MC, Kaufmann CA, Massigoge A, Gutiérrez MA, Rafuse DJ, Scheifler NA, González ME. 2012. Bone modification and destruction patterns of leporid carcasses by Geoffroy's cat (Leopardus geoffroyi): An experimental study. Quaternary International 278: 71-80.

Baladrón AV. 2008. Segregación de nicho trófico entre el lechuzón orejudo (Asio clamator) y la lechuza de campanario (Tyto alba) en un bosque de tala de la región pampeana. In Actas de la XII Reunión Argentina de Ornitología. RAO: San Martin de Los Andes (Argentina); 151.

Burgos JJ. 1968. Los climas de la provincia de Buenos Aires en relación con la vegetación natural y el suelo. In Flora de la Provincia de Buenos Aires Volumen IV, Cabrera AL (ed.). Colección Científica, Instituto Nacional de Tecnología Agropecuaria: Buenos Aires; 33-99.

Cabrera AL. 1976. Regiones fitogeográficas argentinas. Enciclopedia Argentina de Agricultura y Jardinería 2: 1-85.

Carrera JD, Fernández FJ. 2010. Análisis tafonómico de egragrópilas producidas por el lechuzón orejudo (Asio clamator): un caso experimental. In Zooarqueología a Principios del Siglo XXI: Aportes Teóricos, Metodológicos y Casos de Estudio, De Nigris M, Fernández PM, Giardina M, Gil AF, Gutiérrez $M A$, Izeta $A$, Neme $G$ and Yacobaccio HD (eds.). Ediciones del Espinillo: Buenos Aires; 381-386.

Crandall BD, Stahl PW. 1995. Human digestive effects on a micromammalian skeleton. Journal of Archaeological Science 22: 789-797.

del Hoyo J, Elliott A, Sargatal J. (eds.).1999. Handbook of the Birds of the World, vol 5: Barn Owls to Hummingbirds. Lynx Edicions: Barcelona.

Delgado CA, Pulgarín PC, Calderón D. 2005. Análisis de egagrópilas del búho rayado (Asio clamator) en la ciudad de Medellín. Ornitología Colombiana 3: 100-103.

Denys C. 2002. Taphonomy and experimentation. Archaeometry 44: 469-484.

Dewar G, Jerardino A. 2007. Micromammals: when humans are the hunters. Journal of Taphonomy 5: 1-14.

Fernández FJ, del Papa L, Moreira GJ, Prates L, De Santis LJM. 2011. Small mammal remains recovered from two archaeological sites in the middle and lower Negro River valley (Late Holocene, Argentina): Taphonomic issues and paleoenvironmental implications. Quaternary International 245: 136-147. 
Fernández-Jalvo Y, Andrews P. 1992. Small Mammal Taphonomy of Gran Dolina, Atapuerca (Burgos), Spain. Journal of Archaeological Science 19: 407-428.

Gómez GN. 2005. Analysis of bone modification of Bubo virginianus pellets from Argentina. Journal of Taphonomy 3: $1-16$.

Gómez GN. 2007. Predators categorization based on taphonomic analysis of micromammals bone: a comparison to proposed models. In Taphonomy and Zooarchaeology in Argentina, Gutierrez MA, Miotti L, Barrientos G, Mendoni Goñalons $G$, Salemme M (eds.). BAR International Series 1601. Archaeopress: Oxford; 1-16.

Gómez GN, Kaufmann CA. 2007. Taphonomic analysis of Pseudalopex griseus (Gray, 1837) scat assemblages and their archaeological implications. Journal of Taphonomy 5: 59-70.

Hammer Ø. 1999-2011. PAST PAleontological STatistics Version 2.07. Reference manual. Natural History Museum, University of Oslo: Oslo.

Iglesias AC. 2009. Tafonomía de pequeños vertebrados depredados por Buteo polyosoma (Aves, Falconiformes). Licenciature Dissertation, Universidad Nacional de La Pampa, La Pampa (Argentina).

Isacch JP, Bó MS, Martínez MM. 2000. Food habits of the Striped Owl (Asio clamator) in Buenos Aires Province, Argentina. Journal of Raptor Research 34: 235-237.

Leveau LM, Teta P, Bogdaschewsky R, Pardiñas UFJ. 2006. Feeding habits of the barn owl (Tyto alba) along a longitudinal-latitudinal gradient in central Argentina. Ornitologia Neotropical 17: 353-362.

Lezcano MJ. 1991. Análisis preliminar de los restos faunísticos hallados en el sitio Laguna Grande, partido de Campana, provincia de Buenos Aires. Boletín del Centro 2: 95-104.

Lo Coco GE, Courtalon P, Roberto Bó F. 2012.Analisis de egagrópilas del lechuzón orejudo (Pseudoscops clamator) en la zona de Islas de Victoria, Entre Ríos, Argentina.Nuestras Aves 57: 19-21.

Marks JS, Cannings RJ, Mikkola H. 1999. Familia Strigidae (Typical Owls). In Handbook of the Birds of the World, vol. 5: Barn Owls to Hummingbirds, del Hoyo J, Elliott A, Sargatal J (eds.). Lynx Edicions: Barcelona; 76-243.

Marti CD. 1987. Raptor food habits studies. In Raptor Management Techniques Manual, Giron Pendleton BA, Milsap BA, Cline KW, Bird DM (eds.). National Wildlife Federation: Washington, DC; 67-80.

Martínez MM, Isacch JP, Donatti F. 1996. Aspectos de la distribución y biología reproductiva de Asio clamator en la provincia de Buenos Aires, Argentina. Ornitología Neotropical 7: $157-161$.

Massoia E. 1976. Mammalia. In Fauna de Agua Dulce de la República Argentina, Ringuelet R (ed.). Fundación Editorial Ciencia y Cultura: Buenos Aires; 1-128.

Massoia E. 1988. Análisis de regurgitados de Rbinoptynx clamator del partido de Marcos Paz, provincia de Buenos Aires. Boletín científico APRONA 7: 4-16.

Massoia E, Fornes A. 1965. Contribución al conocimiento de los roedores miomorfos argentinos vinculados con la fiebre hemorrágica argentina. Difusión de la Comisión Nacional Coordinadora para el Estudio y Lucha contra la Fiebre Hemorrágica: Buenos Aires.

Medina M, Rivero D, Teta P. 2011. Consumo antrópico de pequeños mamíferos en el Holoceno de Argentina central: perspectivas desde el abrigo rocoso Quebrada del Real 1 (Pampa de Achala, Córdoba). Latin American Antiquity 22. 618-631.

Mengoni Goñalons GL. 1983. Prehistoric utilization of faunal resources in arid Argentina. In Animals and Archaeology 1: Hunters and their Prey, Clutton-Brock J, Grigson C (eds.).

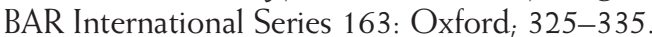

Montalvo CI and Tallade P. 2009. Taphonomy of the accumulations produced by Caracara plancus (Falconidae). Analysis of prey remains and pellets. Journal of Taphonomy 7: 235-248.

Montalvo CI, Tallade P. 2010. Análisis tafonómico de restos no ingeridos de roedores presa de Caracara plancus (Aves, Falconidae). In Zooarqueología a Principios del Siglo XXI: Aportes Teóricos, Metodológicos y Casos de Estudio, De Nigris M, Fernández PM, Giardina M, Gil AF, Gutiérrez MA, Izeta $A$, Neme $G$, Yacobaccio HD (eds.). Ediciones del Espinillo: Buenos Aires; 419-428.

Montalvo CI, Tejerina P. 2010. Análisis tafonómico de los huesos de anfibios y roedores depredados por Athene cunicularia (Strigiformes, Strigidae) en La Pampa, Argentina. In Mamuil Mapu: pasado y presente desde la arqueología pampeana, Berón M, Luna L, Bonomo M, Montalvo CI, Aranda C, Carrera Aizpitarte M (eds.). Editorial Libros del Espinillo: Buenos Aires; 323-334.

Montalvo CI, Pessino MEM and González VH. 2007. Taphonomic analysis of mammals remains eaten by pumas (Puma concolor Carnivora, Felidae) in central Argentina. Journal of Archaeological Science 34: 2151-2160.

Montalvo CI, Pessino MEM, Bagato FC. 2008. Taphonomy of the bones of rodents consumed by Andean hog-nosed Skunks (Conepatus chinga, Carnivora, Mephitidae) in central Argentina. Journal of Archaeological Science 35 : 1481-1488.

Montalvo CI, Bisceglia S, Kin MS, Sosa RA. 2012. Taphonomic analysis of rodent bone accumulations produced by Geoffroy's cat (Leopardus geoffroyi, Carnivora, Felidae) in Central Argentina. Journal of Archaeological Science 39: 1933-1941.

Motta-Junior JC. 2006. Relações tróficas entre cinco Strigiformes simpátricas na região central do Estado de São Paulo, Brasil. Revista Brasileira de Ornitologia 14: 359-377.

Motta-Junior JC, Rodrigues Alho CJ, Silva Belentani SC. 2004. Food habits of the Striped Owl Asio clamator in South-East Brazil. In Raptors Worldwide, Chancellor RD, Meyburg BU (eds.). Working World Group of Birds of Prey and Owls/MME-BirdLife Hungary: Berlin-Budapest 777-784.

Pardiñas UFJ. 1996-1998. Roedores holocénicos del sitio Cerro Casa de Piedra 5 (Santa Cruz, Argentina): tafonomía y paleoambientes. Palimpsesto. Revista de Arqueología 5: 66-90. 
Pardiñas UFJ. 1999. Tafonomía de microvertebrados en yacimientos arqueológicos de Patagonia. Arqueología 9: 265-308.

Pardiñas UFJ, Teta P, Formoso AE, Barberena R. 2011. Roedores del extremo austral: tafonomía, diversidad y evolución ambiental durante el Holoceno tardío. In Bosques, montañas y cazadores. Investigaciones Arqueológicas en Patagonia Meridional, Borrero LA, Borrazo K (eds.). Editorial Dunken: Buenos Aires, Capital Federal, 61-84.

Pautasso A. 2006. Dieta del lechuzón orejudo (Asio clamator) en el centro y este de la provincia de Santa Fe, Argentina. Ornitología Neotropical 17: 289-293.

Pautasso AA, de la Peña MR. 2001. Asio clamator; biología; reproducción, nidificación; Córdoba; Santa Fé. El Hornero 16: 43-46.

Quintana CA. 2005. Despiece de microroedores en el Holoceno Tardío de las Sierras de Tandilia (Argentina). Archaeofauna 14: 227-241.

Rivero D, Salvi VF, Paradela H. 2008. Cambios en la funcionalidad del sitio Arroyo El Gaucho 1 durante el Holoceno (pcia. de Córdoba, Argentina). Revista Arqueología 14: 77-101.
Saavedra B. 1994. Tafonomía de micromamíferos de Chile central. In Actas del $2^{\circ}$ taller de Arqueología de Chile Central. www.arqueologia.cl: Santiago; 1-22.

Simonetti JA, Cornejo LE. 1991. Archaeological evidence of rodent consumption in central Chile. Latin American Antiquity 2: 92-96.

Souttou K, Manaa A, Stoetzel E, Sekour M, Hamani A, Doumandji S, Denys C. 2012. Small Mammal Bone Modifications in Black-Shouldered Kite Elamus caeruleus Pellets from Algeria: Implications for Archaeological Sites. Journal of Taphonomy 10: 1-19.

Stahl PW. 1996. The recovery and interpretation of microvertebrate bone assemblages from Archaeological contexts. Journal of Archaeological Method and Teory 3: $31-75$.

Terry RC. 2007. Inferring predator identity from skeletal damage of small-mammal prey remains. Evolutionary Ecology Research 9: 199-219.

Teta P, Andrade A, Pardiñas UFJ. 2005. Micromamíferos (Didelphimorphia y Rodentia) y paleoambientes del Holoceno tardío en la Patagonia noroccidental extraandina (Argentina). Archaeofauna 14: 183-197. 